\title{
Immunohistochemical expression of anti-oxidants in bovine oviduct epithelial cells of estral and luteal phases
}

\author{
Aytul KURUM ${ }^{1}$, Turgay DEPREM ${ }^{2}$, Hakan KOCAMIS ${ }^{1}$, Siyami KARAHAN ${ }^{1}$ \\ ${ }^{1}$ Kırıkkale University, Faculty of Veterinary Medicine, Department of Histology and Embryology, Yahşihan, Kırıkkale; ${ }^{2}$ Kafkas \\ University, Faculty of Veterinary Medicine, Department of Histology and Embryology, Paşaçayırı, Kars, Turkey.
}

\begin{abstract}
Summary: The present study aimed to evaluate immunohistochemical distributions of anti-oxidative enzymes $\mathrm{Cu} \mathrm{Zn}$ Superoxide dismutase (SOD-1), catalase, and Glutation peroxidase-1 (GPX1) in the bovine oviduct epithelial cells of estral and luteal phases. The results indicated both ciliated and secretoric cells of the oviduct mucosa exibited varying degrees of immureactivity for all. The SOD-1 and GPX1 immunostainings were more conspicuous in luteal phase while catalase immunostaining was more apparent in estral phase, especially in the isthmus region of the oviduct. In contrast to catalase, GPX1 immunoractivity was absent or limited in the isthmus. All regions of the oviduct mucosa had similar SOD-1 immunoreactivity. SOD-1 and GPX1 immunoreactivities were more apparent in samples of the luteal phase while catalase immnureactivity was higher in those of the estral phase. Presence of anti-oxidative enzymes catalase, SOD, and GPX1 immunostainings in the bovine oviduct suggests that the bovine oviduct epithelial cells are most likely engaged into synthesis of such enzymes and possibly the source of anti-oxidative enzymes in oviduct fluid. The oviduct regions, each of which executes different reproductive functions, varied by means of catalase and GPX1 expressions, suggeting that anti-oxidants may possibly contribute to different physiological proceses in the reproductive cycle. Furthermore, anti-oxidant expressions also varied between luteal and estral phases, suggesting that oviduct epithelial cells are possibly influenced by hormonal changes in regard to anti-oxidant expression. Presence of SOD-1 immunoreactivity in some but not all basal cells of the oviduct epithelial lining should be further investigated for possible heterogeneities among basal cells and for origin of secretory and ciliated cells.
\end{abstract}

Keywords: Anti-oxidant, bovine, estral, immunohistochemistry, luteal, oviduct.

\section{Östral ve luteal dönemde sığır ovidukt epitelinde antioksidanların immunohistokimyasal ifadesi}

Özet: Sunulan çalışmada östral ve luteal dönemdeki sığır ovidukt epitelinde, anti-oksidatif enzimler Cu Zn-Süperoksit dismutaz (SOD-1), katalaz, ve Glutaston peroksidaz-1 (GPX1) immünohistokimyasal dağılımının incelenmesi amaçlanmıştır. Immunoperoksidaz test sonuçları ovidukt mukozasında silyalı ve sekretorik hücrelerin katalaz, SOD-1, and GPX1 için değişen derecelerde immunoreaktivite göstermiştir. SOD-1 ve GPX1 immünoreaktiviteleri luteal dönemde daha belirgin iken katalaz östral dönemde özellikle istmusta daha belirgin reaksiyon göstermiştir. Oviduktun tüm bölgeleri benzer SOD-1 immunoreaktivitisi göstermiştir. SOD-1 ve GPX1 luteal fazın örneklerinde, katalaz ise östral dönemin örneklerinde daha belirgin immunoreaktivite göstermiştir. Sığır oviduktunda katalaz, SOD-1, and GPX1 anti-oksidatif enzimlerinin immünoreaktivitesinin yer alması ovidukt epitel hücrelerinin bu enzimleri sentezlediğini ve ovidukt sıvısındaki anti-oksidant enzimlerin kaynağı olabileceğini düşündürmektedir. Farklı reprodüktif fonksiyonları yerine getiren ovidukt bölümleri katalaz ve GPX1 immunoreaktivitesi açısından farklılık göstermektedir. Bu durum anti-oksidanların seksüel siklüsta farklı fizyolojik süreçlere katılma olasılıklarını düşündürmektedir. Ayrıca luteal ve östral dönem arasında anti-oksidanların göstermiş olduğu farklı immunreaksiyonun ovidukt epitel hücrelerinin üreme hormonlarından anti-oksidant ekspresyonu açısından etkilendiğini düşündürmektedir. SOD-1 immünoreaktivitesinin ovidukt epitelindeki bazal hücrelerin bazılarında görülüp bazılarında görülmemesi, bu hücrelerdeki gerek heterojenite gerekse silyalı ve sekretorik hücrelerin kökenleri açısından incelenmesi gerekmektedir.

Anahtar sözcükler: Anti-oksidant, immunohistokimya, luteal, ovidukt, östral, sığır.

\section{Introduction}

The oviduct is an important part of the reproductive system and fosters an environment required for fertilization, early embryonic development and transport of oocyte and embriyo to the uterus $(29,28)$. It also contributes to sperm capasitation $(28,11)$. Although the oviduct mucosa varies among species, it is generally lined by simple columnar epithelia, which is mainly consisted of ciliated and secretoric cells (31). Ciliated cells contribute to transport of oocyt and zygote (24) while secretoric cells secrete nutritious oviduct fluid, which is needed for survival of oocyte and embryo (29). The isthmus, known as sperm reservoir, prevents polyspermi and preserves sperm motility (35). During the 
sexual cycle, numerous cascades of events with several metabolic pathways occurs in the oviduct that result in numerous metabolic end products and by-products including reactive oxygen species (ROS) that pose serious threat to cells and tissues (2).

Reactive oxygen species (ROS) are continuously formed as regular by-products of cellular metabolism $(36,19)$. At optimum concentrations, ROS are considered as essential molecules for several physiological processes and events such as cell differentiation, apoptosis, cell immunity and cellular defense against microorganisms (34). In the female reproductive system, ROS contribute to oocyte maturation and steroidogenesis. At low levels, ROS induce oocyte maturation (10), in vitro fertilization, sperm functions and embryo development (9). Low levels of ROS in the female reproductive tract seems to be critical for sperm attachment to oocytes (15) and subsequent implantation to the uterus (3). Presence of excess ROS, so called oxidative stress, harms cells by damaging cellular lipids, proteins, and DNA and thus they eventually impair cell functions (6). The balance between ROS and antioxidants is important for reproductive system as well, and has direct influence on oocyte maturation, sperm functions, fertilization, and embryo development (7). The oviduct, the fertilization site, should also keep this balance to foster such an optimum environment to promote sperm capasitation and oocyte maturation, fertilization and early embryonic development $(15,14)$. Cells have several anti-oxidative pathways to detoxify ROS by employing various antioxidants including glutathione peroxidase (GPX), Copper, zinc superoxide dismutase (CuZnSOD-SOD-1), manganese dismutase (MnSOD), and catalase (19). The CuZnSOD and MnSOD are found primarily in cytoplasm and mitochondria, respectively and catalyze $\mathrm{O}_{2}+\mathrm{O}_{2}+2 \mathrm{H}=$ $\mathrm{O}_{2}+\mathrm{H}_{2} \mathrm{O}_{2}$. In turn, $\mathrm{H}_{2} \mathrm{O}_{2}$ is decomposed to $\mathrm{H}_{2} \mathrm{O}$ and oxygene in peroxisomes by antioxidants catalase and GPX $(33,18)$. However, it is well known that execessive amounts of ROS are detrimental to cells (6). Thus, there should be antioxidants present in the oviduct to control ROS levels and the major antioxidants should be determined in every species including cow, an economically important species.

There has been strong scientific evidence for ROS involvement in the reproductive physiology and pathologies. However, there has been a continous and growing effort to further reveal presence of ROS in the female reproductive tract with respect to their roles in the reproductive physiology at lower and higher concentrations. Thus, in the present study, we aimed to evaluate immunohistochemical distributions of antioxidative enzymes catalase, SOD, and GPX1 in the bovine oviduct of estral and luteal phases.

\section{Material and Methods}

Tissue collections: The bovine oviduct samples were obtained from a local slaughterhouse (Kırıkkale, Turkey) upon evaluation of ovaries for presence of any follicules or corpus lutea (27). The phase of reproductive cycle was determined according to the ovarial morphology as luteal or estral phases. Then, the oviduct was further divided into sections as fimbria, ampulla and isthmus. The oviducts samples were collected from each section and kept in 10\% formalin for 24 hours. Following routing dehydration procedure, the samples were embedded into parafine blocks and cut at a thickness of $5 \mu \mathrm{m}$. The status of the reproductive cycle was also further confirmed by histology.

Immunohistochemical staining: An avidin-biotinperoxidase $(A B C)$ technique (12) was used to determine immunohistochemical distribution of GPx-1, SOD-1 and catalase in the oviduct. The sections were processed for immunohistochemical staining following deparrafinization and rehydration. The endogenous peroxidase activity was quenched by incubating samples in $3 \% \mathrm{H}_{2} \mathrm{O}_{2}$ for $10 \mathrm{~min}$. The samples were then boiled in $0.1 \mathrm{M}$ sitrat buffer $(\mathrm{Ph}$ 6.0) in a microwave oven ( 800 watt) for $10 \mathrm{~min}$. The samples were incubated in $10 \%$ blocking serum (Ultra V Blok) for $10 \mathrm{~min}$ to prevent non-specific binding. Samples were then incubated either with anti-SOD-1 (Thermo Scientific Pierce Products: LF-PA0013; at a dilution of 1:250), anti-GPX1 (Abcam: ab22604; at a dilution of 1:750) or catalase (Abcam: ab1877; at a dilution of 1:1500) for an hour at room temperature. The samples were further incubated for 30 min with a secondary antibody (Ultravision Detection system AntiRabbit, Biontinylated Goat Anti-Rabbit, Lab.Vision510.991.2800). The samples were then incubated with streptavidin horse radish peroxidase at room temperature for $30 \mathrm{~min}$ and then with $\mathrm{DAB}$ chromogen for coloring reaction (Shu et al., 1988). At each step, samples were washed in PBS. After DAB staining, the samples were counterstained with hematoxylin and coverslipped. The immunostained samples were examined and photographed using a light microscope (Lieca DM 5000B).

\section{Results}

SOD-1: The SOD-1 immunoreactivity is observed in ciliated and secretoric cells of the oviduct epithelial lining. The ciliated cells expressed cytoplasmic and nuclear immunostaining while secretoric cells often had cytoplasmic immunostaining. The immunoreactivity was localized mainly at the apical sites of cells (Fig 1A). Some of the basal cells had nuclear immunoreactivity, while some basal cells did not have any immunoreactivity (Fig 1B). The oviduct regions were similar in SOD-1 immunoreactivity pattern. The intensity 


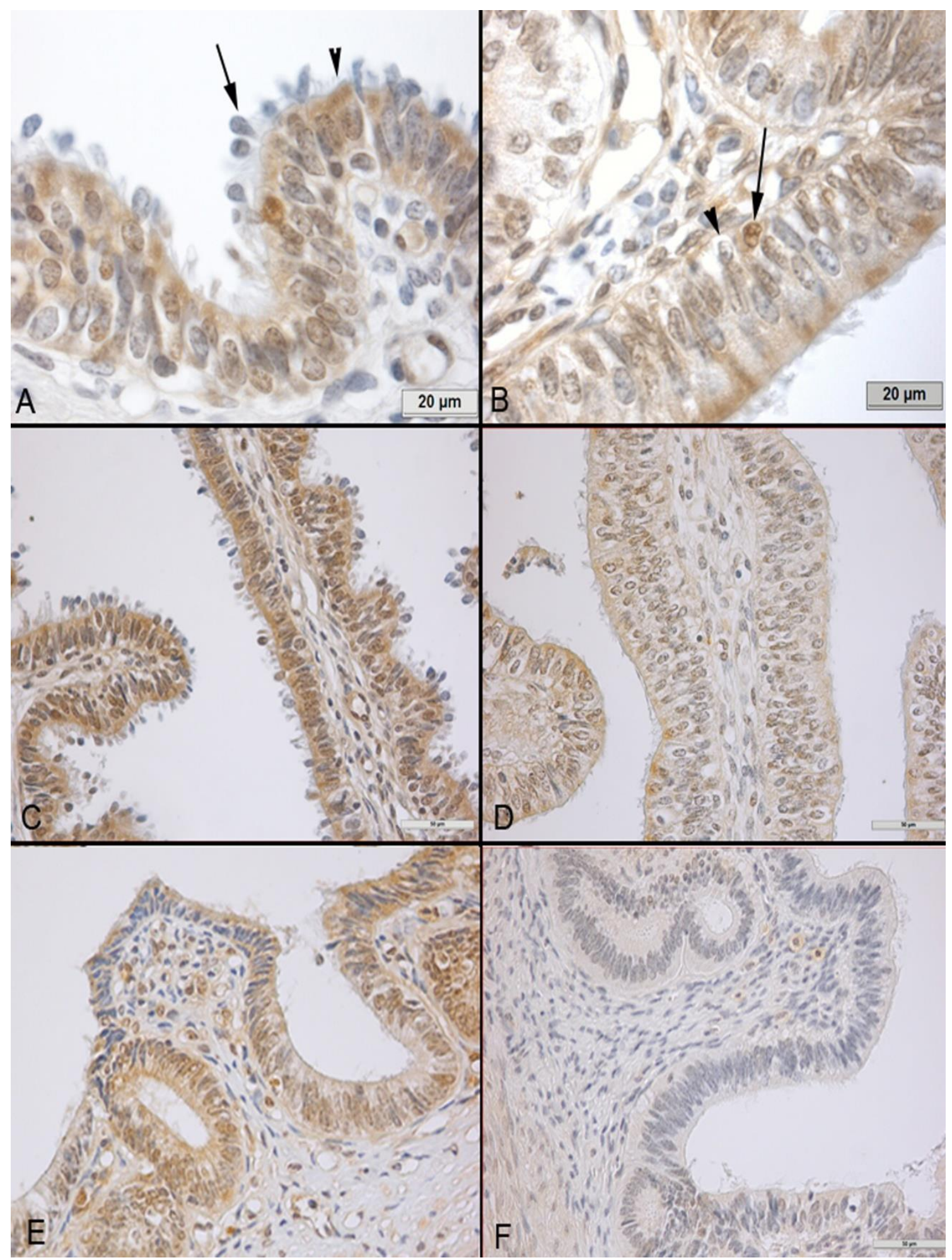

Figure 1. Immunostaining of SOD-1 in the bovine oviduct. A) Cytoplasmic and nuclear immunostainings were present especially in ciliated cells. Cytoplasmic staining is mainly localized at the apical sites (arrow head) of the cells. Both type of stainings can be seen in this section of the ampulla of the luteal phase, which is characterized by nuclear loss (arrow). B) Some basal cells expressed SOD (arrow) while the others did not (arrow head), which is exemplified by this section of the ampulla of the estral phase. C) The SOD-1 expression was higher in the fimbria of the luteal phase compared D) to that of the estral phase. E) Likewise SOD staining was more conspicuous in the sections of the istmus at the luteal phase compared to F) those of the estral phase.

Şekil 1. Sığır oviduktunda SOD-I immun boyaması. A) Özellikle silyalı hücrelerde sitoplazmik ve nükleer boyanma bulunmaktadır. Sitoplazmik boyanma esas olarak hücrelerin apikalinde yerleşmiştir (ok başı). Çekirdek atılışları ile karakterize olan luteal dönemde ampullada luteal dönemde her iki tür boyanma görülüyor. B) Bazı bazal hücrelerde SOD-I pozitif iken (ok), diğerleri negatif (ok baş1), östral dönem- ampulla. SOD-I ekspresyonu luteal dönemde fimriyada C), östral döneme göre (D) daha fazla. İstmusta da benzer şekilde luteal dönemde (E), östral döneme göre daha fazla. 


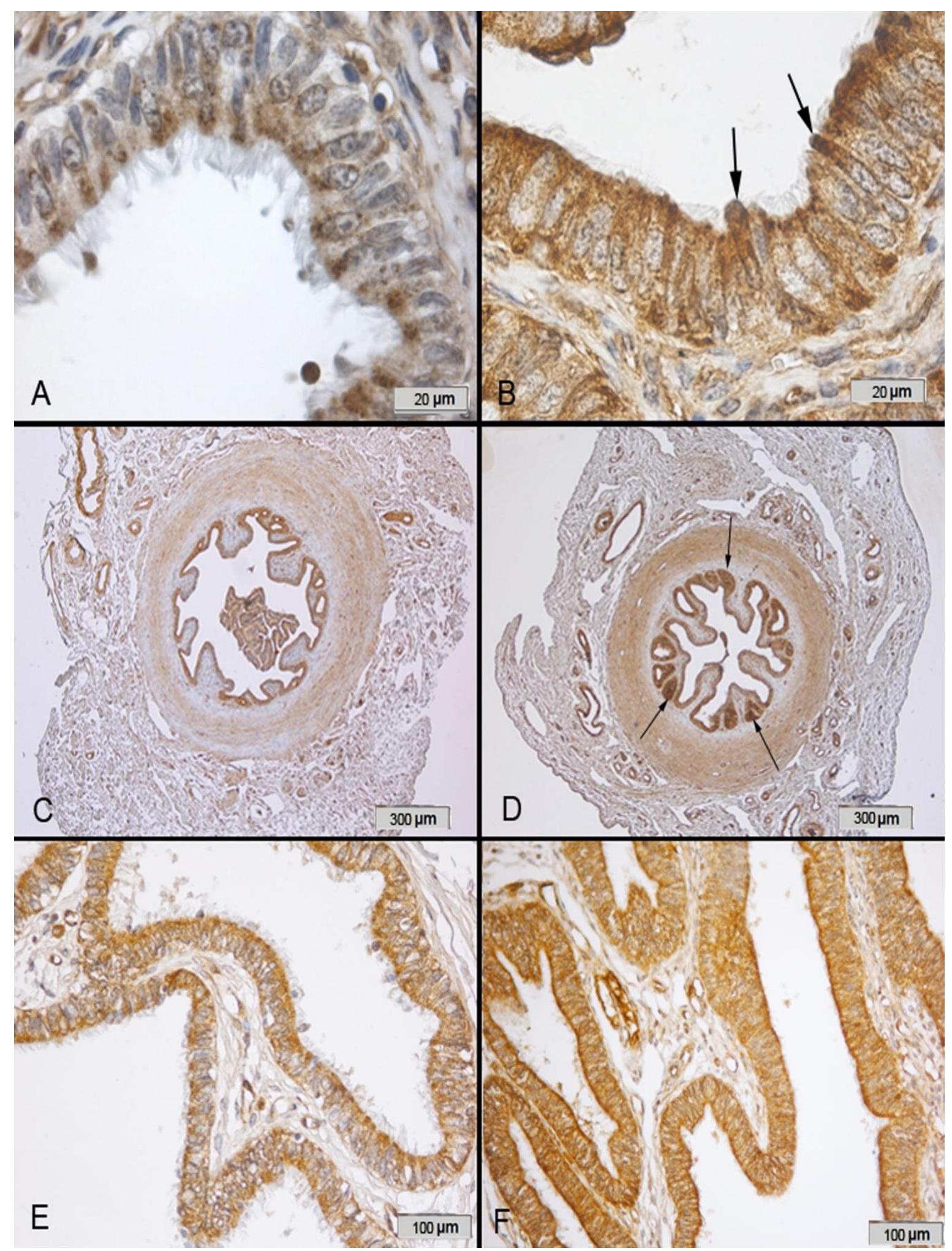

Figure 2. Immunostaining of catalase in the bovine oviduct A) Catalase immunostaining was located in cytoplasm of ciliated and secretoric cells of the oviduct. Immunoreactivity was especially observed in ciliated cells, which is exemplified by this section of the ampulla of the luteal phase. B) Immunostaining was also seen in protrusions of secretoric cells (arrows) that can be seen in this section of the ampulla of the estral phase. C) Immunostaining was also seen in the isthmus but less intese in the sections of the luteal phase compared to D) those of the estral phase. E) Immunostaining was seen in the fimbria, but the intensity of immunostaining was less in the luteal phase compared to F) those of the estral phase.

Şekil 2. Sığır oviduktunda Katalaz immun boyaması. A) Katalaz reaksiyonu oviduktta silyalı ve sekretorik hücrelerin sitoplazmasında bulunmaktadır. İmmunreaktivite özellikle de silyalı hücrelerde görülmektedir, östral dönem, ampulla. B) Östral dönemde ampullada ise sekretorik hücrelerin protrüzyonlarında da (ok) görülmektedir. C) İmmun boyama luteal dönemde östral döneme (D) göre daha az yoğunluktadır. E) İmmun boyamaLuteal dönemde östral döneme (F) göre fimbriyada daha az yoğundur. 


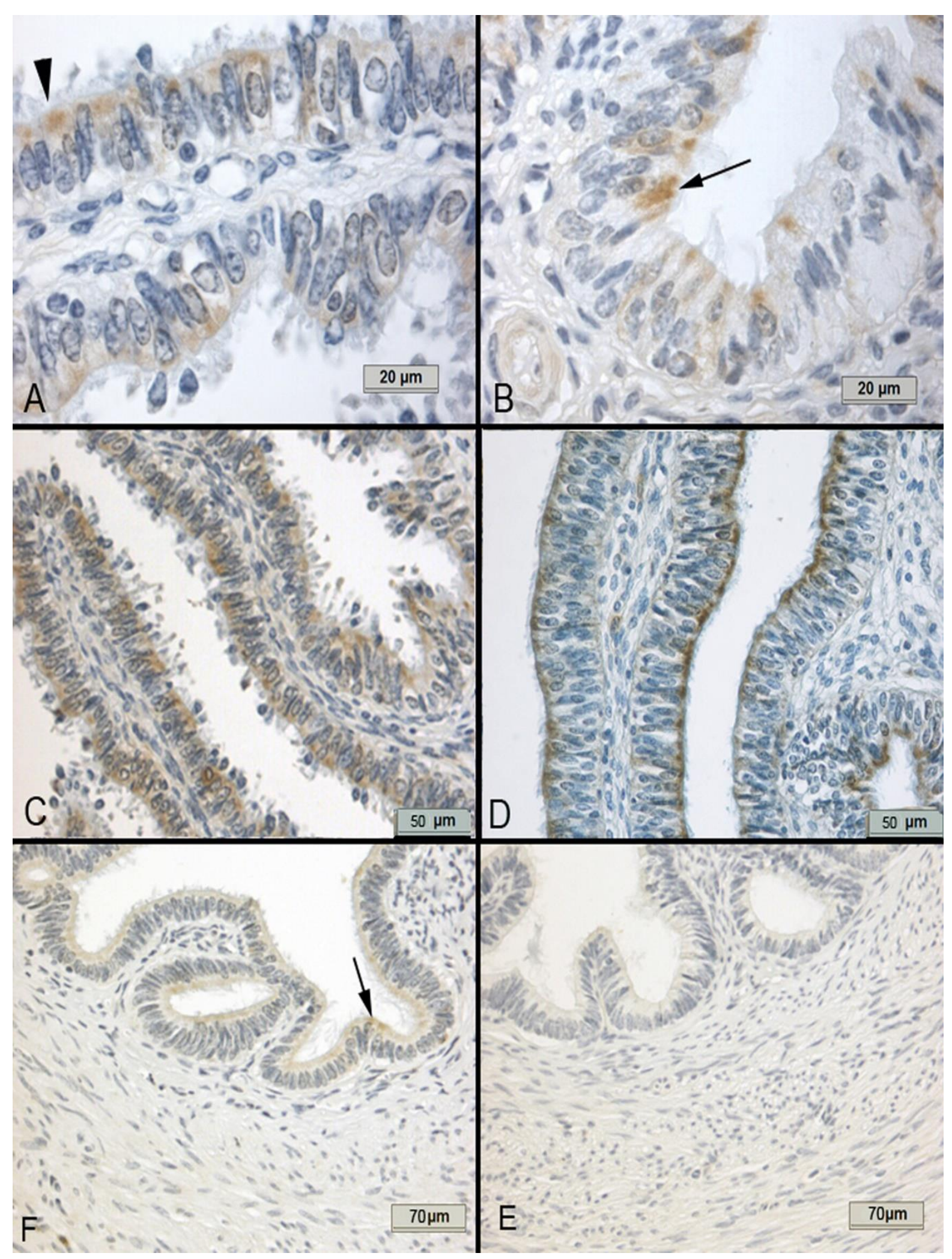

Figure 3. Immunostaining of GPX1 in the bovine oviduct. A) The GPX1 immunoreactivity was specifically cytoplasmic and mainly localized to apical sites of the ciliated cells (arrow head), exemplified by the ampulla of the luteal phase B) At the estral phase, the immunreactivity was generally observed in a small number of ciliated cells (arrow), exemplified by this section of the ampulla. C) The fimbria of the luteal phase has intense immunoreactivity D) compared to those of the estral phase E) The isthmus had minimal immunoreactivity at the luteal phase while F) it had almost no immunoreactivity at the estral phase.

Şekil 3. Sığır oviduktunda GPX1 immun boyaması. A) GPX1 immunreaktivitesi özellikle sitoplazmik olarak ve de silyalı hücrelerin apikalinde (ok başı) yerleşmiştir, luteal dönem, ampulla. B) Östral dönemde immunreaktivite az sayıda silyalı hücrede (ok) gözlenmiştir, ampulla. C) Luteal dönemde fimriyada immunreaktivite östral döneme (D) göre daha yoğundur. E) İstmusta luteal dönemde immunreaktivite minimum iken östral dönemde (F) reaksiyon bulunmamaktadır. 
Table 1. Evaluation of the intesity of immunostating in epithelial cells of the bovine oviduct sections based on sexual cycle. Tablo 1. İmmunreaksiyonların şiddetinin dönemlere ve oviduktun bölgelerine göre ovidukt epitelinde değerlendirilmesi.

\begin{tabular}{lcccccc}
\hline & \multicolumn{2}{c}{ Fimbria } & \multicolumn{2}{c}{ Ampulla } & \multicolumn{2}{c}{ Isthmus } \\
\hline & Cillium cells & Secretoric cells & Cillium cells & Secretoric cells & Cillium cells & Secretoric cells \\
\hline Sod-I (Luteal) & +++ & ++ & +++ & ++ & + & + \\
Sod-I (Östral) & ++ & + & + & ++ & - & - \\
Catalase (Luteal) & ++ & + & ++ & + & ++ \\
Catalase (Östral) & +++ & ++ & +++ & +++ & ++ \\
GPX-I (Luteal) & +++ & ++ & ++ & + & + \\
GPX-I (Östral) & ++ & + & ++ & + & - \\
\hline
\end{tabular}

+ Lightly (Az yoğun), ++ Moderate (Orta şiddette yoğun), +++ Intense (Çok yoğun ), - Negative (Negatif)

of immunostaining was higher in samples the luteal phase compared to those of the estral phases (Figs 1C, 1D, 1E, 1F). The distribution of the SOD-1 immunoreactivity in oviduct epithelial cells of the bovine oviduct is presented in Table 1 according to two different phases of the sexual cycle.

CATALASE: The catalase immunostaining was located in cytoplasm of ciliated and secrotoric cells of the bovine oviduct (Fig 2A). Immunostaining was also seen in protrusions of secretoric cells (Fig 2B). In general, the isthmus had intense immunostaining compared to the other regions especially at the estral phase (Fig 2D). The intensity of catalase immunostaining was higher in the samples of the estral phase compared to those of the luteal phase in every sections of the bovine oviduct (Fig $2 \mathrm{C}, 2 \mathrm{D}, 2 \mathrm{E}, 2 \mathrm{~F})$. The distribution of the catalase immunoreactivity in oviduct epithelial cells of the bovine oviduct is presented in Table 1 according to two different phases of the sexual cycle.

GPX1: The GPX1 immunoreactivity was cytoplasmic and mainly localized to apical sites of the ciliated cells (Fig 3A). In general, Immunostaining is less intense in the sections of the estral phase compared to those of the luteal phase (Fig 3A, 3B, 3C, 3D, 3E, 3F). The immunoreactivity was either absent or minimal in the isthmus of both phases (Fig 3E). The isthmus had minimal immunoreactivity at the luteal phase (Fig 3E) while it had almost no immunoreactivity at the estral phase (Fig 3F). The distribution of the GPX-1 immunoreactivity in oviduct epithelial cells of the bovine oviduct is presented in Table 1 according to two different phases of the sexual cycle.

\section{Discussion and Conclusion}

The mammalian oviduct, also called fallopian tube, fosters an optimal environment for oocyte maturation, sperm maturation, fertilization and early embryonic development $(5,29)$. The oviduct epithelial cells secrete and predominantly determine the characteristics of oviduct luminal fluid (26). Recent reports indicated ROS including superoxide anion and hydrogen peroxide at optimum levels contribute to sperm capasitation (21), oocyte maturation and fertilization (25). As claimed by Vandaele et al. (37), exposure of oocyte during maturation to hydrogen peroxide for a short period improves development of bovine embryos. Sperm itself produces ROS (13). On the other hand, higher levels of ROS cause damages to sperm, oocyte, embryo and oviduct epithelial cells (ROS). Our study supports the notions that there is an anti-oxidative mechanism in the oviduct with a number of anti-oxidants including SOD, GPX1 and catalase $(15,30)$. Our study indicated both ciliated and secretory cells in the bovine oviduct mucosa contribute to the anti-oxidant mechanism as both cell types express the anti-oxidants. Catalase and SOD were expressed both in ciliated and secretory cells while GPX1 was expressed mainly in ciliated cells. As reviewed by Lapointe et al. (16) anti-oxidants including catalase are present in the oviduct luminal fluid. We also propose that the oviduct secretory and ciliated epithelial cells are most likely the predominat sources of anti-oxidative enzymes in luminal fluid, which has protective properties on sperm, oocyte and embryo. The oviduct epithelial cells are responsible for preservation of the microenvironment of the lumen as well as preparation of the oviduct for fertilization and survival of the developing embryo before its transport to the uterus (20).

The oviduct responds to hormonal changes that occur during different phases of the reproductive cycle and secrectes various kinds of molecules including cytokines, enzymes, calcium, magnesium, phosphate, and bicarbonate ions (20). The oviduct epithelia may secrete different anti-oxidants during different phases of the cycle. Lapointe and Bilodeau (2003) reported that the highest level of GPX1 mRNA expression toward the end of the cycle just before ovulation. Catalase activity occurred at the mid and end of the cycle while SOD-1 activity remained constant throught the cycle. Roy et al (30) reported that $\mathrm{Cu}, \mathrm{ZnSOD}$ is the lowest during the metestrus. In our study, the SOD and GPX1 
immunostainings were higher in every segments of the bovine oviduct in the samples of the luteal phase compared to those of the estral phases while catalase immunoreactivity was higher in the estral phase. Our finding on catalase supports the fact that catalase in the oviduct fluid binds to sperm acrosomal cap to enhance sperm survival and capacitation (16).

The oviduct is traditionally divided into three parts: fimbria, ampulla and isthmus $(4,5)$ and each one them has specific roles in reproduction (8) For instance, the ishtmus is considered as the sperm reservoir (17) while ampulla is the site of fertilization (8). Each oviduct part may differ by means of anti-oxidant activity or expression (15). Lapointe and Bilodeau (15) reported that SOD expression was similar throught the oviduct while GPX1 and GPX-2 expressions were the highest in the ampulla and fimbria while GPX-3 expression was higher in the isthmus. Roy et al. (30) claimed that SOD-1 expression was higher in the ampulla. In the present study, the SOD-1 immunostaining is similar throught in all regions. The GPX1 immunoreactivity was either absent or minimal in the isthmus. Cells in the isthmus folds had intense catalase immunostaining especially at the estral phase. Thus, as previously mentioned by Roy et al. (30) we also think that catalase has specific activity in the isthmus, possibly in sperm preserving and final capasition.

The oviduct epithelial lining is composed mainly of ciliated and secretory cells (22). Another cell type, which is called reserve cell or basal cell, has also been defined and categorized predominantly $\mathrm{T}$ lymphocytes (23). Abughrien et al (1) classified two types of basal cells in the oviduct. The first one is classified as lymphocyte with condensed heterochromatin. The second one was classified as macrophage with heterochromatin typically clumped around the nuclear envelope. Paik et al. (22) defined a tubal stem like cell, namely peg cell. It is obvious that there is an ongoing effort to reveal how epithelial cells regenarate and what the origin of secretory and ciliated cells are. One of the striking scientific evidence in the study is that some of the basal cells are SOD immunopositive and some of the basal cells are SOD immunonegative. One of the arguments, we also raise, is whether ciliated and secretory cells of the oviduct possibly have different origins. We suggest that such a difference in SOD immunostaining in basal cells in the bovine oviduct should be further studied with respect to SOD activity in stem cells or progenitor cells in future studies.

In conclusion, the bovine oviduct epithelial cells express anti-oxidants SOD-1, GPX1 and catalase. All regions of the oviduct have similar SOD-1 immunoreactivity. The isthmus has minimal GPX1 expression while it has the highest catalase expression. SOD-1 and GPX1 expressions were higher during the luteal phase, while catalase expression is higher during the estral phase of the reproductive cycle. Variation in anti-oxidant expressions in different regions of the oviduct indicates that different anti-oxidants may engage in different functions in the bovine oviduct. Anti-oxidant expressions also vary between luteal and estral phases of the reproductive cycle, indicating possible hormonal influence on epithelial cells by means of anti-oxidant synthesis.

\section{References}

1. Abughrien BM, Dore MAP, McGeady TA, Fitzpatrick E (2000): Intraepithelial Leucocytes in the bovine uterine tube. Cells Tissues Organs, 166, 20-30.

2. Agarwal A, Aponte-Mellado A, Premkumar BJ, Shaman A, Gupta S (2012): The effects of oxidative stress on female reproduction: a review Reprod Biol Endocrinol, 10,49-70.

3. Agarwal A, Gupta S, Sharma RK (2005): Role of oxidative stress in female reproduction. Reprod Biol Endocrinol, 3, 28.

4. Aughey E, Frye FL (2001): Female reproductive system. 188 In: Comparative Veterinary Histology. Manson Publishing London pp.

5. Bhatt P, Kadam K, Saxena A, Natraj U (2004): Fertilization, embryonic development and oviductal environment: role of estrogen induced oviductal glycoprotein. Indian J Exp Biol, 42, 1043-1055.

6. Celi P (2010): The role of oxidative stress in small ruminants' health and production. R Bras Zootec, 39, 348363.

7. Chandra A, Surti N, Kesavan S, Agarwal A (2009): Significance of oxidative stress in human reproduction. Arch Med Sci 1A, 28-32.

8. Erdost H (2010): Dişi Genital Sistem. 232 In: Özer A (Ed), Veteriner Özel Histoloji Nobel Yayın Dağıtım, Ankara.

9. Guerin P, Mouatassim SEl, Menezo Y (2001): Oxidative stress and protection against reactive oxygen species in the pre-implantation embryo and its surroundings. Hum Reprod Update, 7, 175-189.

10. Gupta S, Ghulmiyyah J, Sharma R, Halabi J, Agarwal A (2014): Power of proteomics in linking oxidative stress and female infertility. BioMed Research International http://dx.doi.org/10.1155/2014/916212.

11. Holt WV, Fazeli A (2010): The oviduct as a complex mediator of mammalian sperm function and selection. Mol Reprod Dev, 77, 934-943.

12. Hsu S M, Raine L, Fanger H (1981): Use of AvidinBiotin-Peroxidase Complex $(A B C)$ in immunoperoxidase techniques: a comparison between $A B C$ and unlabeled antibody (PAP) procedures. J Histochem Cytochem, 29, 577-580.

13. Koppers AJ, De Iuliis GN, Finnie JM, McLaughlin EA, Aitken RJ (2008): Significance of mitochondrial reactive oxygen species in the generation of oxidative stress in spermatozoa. J Clin Endocrinol Metab, 93, 3199207.

14. Lapointe J, Kimmins S, Leslie AM, Bilodeau JF (2005): Estrogen Selectively Up-Regulates the Phospholipid 
Hydroperoxide Glutathione Peroxidase in the Oviducts. Endocrinology, 146, 2583-2592.

15. Lapointe J, Bilodeau JF (2003): Antioxidant Defenses Are Modulated in the Cow Oviduct During the Estrous Cycle. Biol Reprod, 68, 1157-1164.

16. Lapointe S, Sullivan R, Sirard MA (1998): Binding of a bovine oviductal fluid catalase to mammalian spermatozoa. Biol Reprod, 58, 747-753.

17. Levebvre R, Chenoweth PJ, Drost M, LeClear CT, MacCubbin M, Dutton JT, Suarez SS (1995): Characterization of the Oviductal Sperm Reservoir in Cattle. Biol Reprod, 53, 1066-1074.

18. Maritim AC, Sanders RA, Watkins III JB (2003): Diabetes, oxidative stress, and antioxidants: a review. $\mathrm{J}$ Biochem Molecular Toxicology, 17, 24-38.

19. Mates JM (2000): Effects of antioxidant enzymes in the molecular control of reactive oxygen species toxicology. Toxicology, 153, 83-104.

20. McNutt-Scott TL, Harris C (1998): Modulation of intracellular glutathione and cysteine metabolism in bovine oviduct epithelial cells cultured in vitro. Biol Reprod, 59, 314-20.

21. O'Flaherty CM, Beorlegui NB, Beconi MT (1999): Reactive oxygen species requirements for bovine sperm capacitation and acrosome reaction. Theriogenology, 52, 289-301.

22. Paik DY, Janzen DM, Schafenacker AM, Velasco VS, Shung MS, Cheng D, Huang J, Witte ON, Memarzadeh S (2012): Stem-like epithelial cells are concentrated in the distal end of the fallopian tube: A site for injury and serous cancer initiation. Stem Cells, 30, 2487-2497.

23. Peters WM (1986): Nature of "basal" and "reserve"cells in oviductal and cervical epithelium in man. J Clin Pathol, 39, 306-312.

24. Priedkalns J, Leiser R (2006): Female Reproductive System. 262-265 In: Jo Ann Eurell (ed), Dellman's Textbook of Veterinary Histology. Blackwell Publishing, Iowa.

25. Riley JC, Behrman HR (1991): Oxygen radicals and reactive oxygen species in reproduction., 198, 781-91.

26. Rodriguez-Martinez H (2007): Role of the oviduct in sperm capacitation. Theriogenology, 68S, 138-146.

27. Rosenberg G, Dirksen G, Gründer HD, Grunert E, Krause D, Stöber M (1979). Femal genital system. In: Clinical Examination of Cattle. Ed: G. Rosenberg.Verlag Paul Parey, Berlin and Hamburg, p.: 329.
28. Rosenfeld CH., Schatten H (2007): Overview of Female Reproductive Organs. 103-104 In: Schatten H, Constantinescu GM. (ed), Comparative Reproductive Biology. Blackwell Publishing, Iowa.

29. Ross MH, Pawlina W (2011): Female Reproductive System. In: Histology A Text and Atlas. Lippincott Williams \&Wikins, pp.845-848.

30. Roy M, Gauvreau D, Bilodeau JF (2008): Expression of superoxide dismutases in the bovine oviduct during the estrous cycle. Theriogenology, 70, 836-842.

31. Samuelson DA (2007): Female Reproductive System. 457459 In: Textbook of Veterinary Histology. Saunders Elsevier, Florida.

32. Shu S, Ju G, Fan L (1998): The glucose oxidase-dabnickel in peroxidase histochemistry of the nervous system. Neuroscience Lett, 85, 169-171.

33. Shull S, Heintz NH, Periasamy M, Manohar M, Janssen YMW, Marsh JP, Mossmann BT (1991): Differential regulation of antioxidant enzymes in response to oxidants. J Biol Chem, 266, 24398-24403.

34. Spooner R, Yilmaz O (2011): The Role of ReactiveOxygen-Species in Microbial Persistence and Inflammation. Int J Mol Sci, 12, 334-352.

35. Suarez SS, Brockman K, Lefebvre R (1997): Distribution of Mucus and Sperm in Bovine Oviducts after Artificial Insemination: The Physical Environment of the Oviductal Sperm Reservoir. Biol Reprod, 56, 447-453.

36. Uttara B, Singh AV, Zamboni P, Mahajan RT (2009): Oxidative Stress and Neurodegenerative Diseases: A Review of Upstream and Downstream Antioxidant Therapeutic Options. Current Neuropharmacology, 7, 65-74.

37. Vandaele L, Thys M, Bijttebier J, Langendonckt AV, Donnay I, Maes D, Meyer E, Soom AV (2010): Shortterm exposure to hydrogen peroxide during oocyte maturation improves bovine embryo development. Society for Reproduction and Fertility, DOI: 10.1530/REP-090430 .

Geliş tarihi: 20.01.2015 / Kabul tarihi: 29.06.2015
Address for correspondence:
Asst.Prof.Dr. Aytül Kürüm
Klrkkale University,
Faculty of Veterinary Medicine,
Department of Histology and Embryology,
71451 Yahşihan, Kırlkkale, Turkey
e-mail:aytululum@hotmail.com 